\title{
STRATEGI PENGEMBANGAN USAHA INDUSTRI KERAJINAN BAMBU BATIK UD. BETRIS DI KELURAHAN MERAS KECAMATAN BUNAKEN KOTA MANADO
}

\author{
Julia Lendombela \\ Melsje Y. Memah \\ Agnes E. Loho
}

\begin{abstract}
This study aims to identify internal factors and external factors of UD Betris, as well as to determine the strategy for developing the business of bamboo batik handicraft industry UD Betris. Betris in Meras Village. This research was conducted from April to June 2018. The data used were primary data and secondary data. Primary data is obtained through observation and interviews which are divided into two parties, namely internal parties (business owners and labor) and external parties (local government and consumers) with 8 (eight) respondents. Meanwhile, secondary data was obtained from literature studies. Analysis of the data used is by using a SWOT analysis. The results showed that internal factors include: raw materials, quality of raw materials, price of raw materials, product uniqueness, business spirit and craftsman skills, product prices, product durability and quality, not having financial records, traditional production equipment, product arrangement that has not been arranged neat, promotion is not efficient, does not have a special place of business, and there is no parking space. external factors include: high market opportunities, government support, opportunities for training, opportunities to participate in exhibitions, plastic substitute goods, interest in business successors, and the existence of competitors using modern production tools. Based on the SWOT diagram, the chosen strategy is a combination of SO, namely: 1) Maintaining product quality and continuing to develop products by innovating to create bamboo handicraft products with new designs. 2) Continue to work with the government and related agencies to develop and expand marketing areas so that products are better known to local and foreign communities through training and exhibition events. *jnkd*.
\end{abstract}

Keywords: small and medium industries, bamboo handicrafts, SWOT, Meras Village, Bunaken District, Manado City.

\section{ABSTRAK}

Penelitian ini bertujuan untuk mengidentifikasi faktor internal dan faktor eksternal, serta untuk mengetahui strategi pengembangan usaha industri kerajinan bambu batik UD. Betris di Kelurahan Meras. Penelitian ini dilaksanakan pada bulan April sampai Juni 2018. Data yang digunakan adalah data primer dan data sekunder. Data primer diperoleh melalui observasi dan wawancara yang dibagi atas dua pihak yaitu pihak internal (pemilik usaha dan tenaga kerja) dan pihak eksternal (pemerintah setempat dan konsumen) dengan jumlah responden 8 (delapan). Sedangkan, data sekunder diperoleh dari studi literatur. Analisis data yang digunakan adalah dengan menggunakan analisis SWOT. Hasil penelitian menunjukan bahwa faktor internal meliputi: bahan baku, kualitas bahan baku, harga bahan baku, keunikan produk, jiwa bisnis dan keterampilan pengrajin, harga produk, ketahanan dan kualitas produk, belum memiliki pencatatan keuangan, alat produksi tradisional, penataan produk yang belum tertata rapi, promosi belum efisien, belum memiliki tempat khusus usaha, dan belum ada tempat parkir. faktor eksternal meliputi: peluang pasar yang tinggi, dukungan pemerintah, kesempatan mengikuti pelatihan, kesempatan mengikuti pameran, barang subtitusi berbahan baku plastik, minat penerus usaha, dan adanya pesaing dengan menggunakan alat produksi modern. Berdasakan diagram SWOT, maka strategi yang terpilih adalah kombinasi SO yaitu: 1) Mempertahankan kualitas produk dan tetap mengembangkan produk dengan cara berinovasi untuk menciptakan produk-produk kerajinan bambu dengan design baru. 2) Tetap bekerja sama dengan pemerintah dan dinas terkait untuk mengembangkan dan memperluas daerah pemasaran agar produk lebih dikenal masyarakat lokal bahkan mancanegara melalui kegiatan pelatihan dan pameran yang diselenggarakan. *jnkd*.

Kata kunci: industri kecil menengah, kerajinan bambu, SWOT, Kelurahan Meras, Kecamatan Bunaken Kota Manado.

Agrisosioekonomi:

Jurnal Transdisiplin Pertanian (Budidaya Tanaman, Perkebunan, Kehutanan, Peternakan, Perikanan), Sosial dan Ekonomi 


\section{PENDAHULUAN}

\section{Latar Belakang}

Pengembangan industri kecil penting bagi struktur industri di Indonesia sehingga dengan investasi kecil dapat berproduksi secara efektif meskipun tingkat perkembangan sektor industri kecil menengah di Indonesia masih relatif rendah.

Sampai saat ini IKM menyumbang 34,56 persen terhadap pertumbuhan industri pengolahan nonmigas secara keseluruhan. Angka ini dapat tercapai karena dukungan lebih kurang 3,6 juta unit usaha, yang merupakan 90 persen dari total unit usaha industri nasional. Serapan tenaga kerjanya yang mencapai 10,3 juta orang, tentunya berdampak pada meningkatnya ekonomi nasional serta mengurangi kemiskinan.

Industri kecil dan menengah (IKM) merupakan sektor yang diharapkan dapat menciptakan kesempatan kerja karena pada sektor ini teknologi yang digunakan dalam proses produksinya lebih banyak menggunakan tenaga kerja manusia sehingga diharapkan dapat menyerap tenaga kerja lebih banyak. Industri kecil dan menengah (IKM) juga memberikan dampak yang positif dalam perekonomian di Indonesia karena menjadi salah satu upaya dalam mengurangi tingkat pengangguran dan kemiskinan.

Salah satu sektor dari industri kecil dan menengah (IKM) adalah industri kerajinan. Industri kerajinan merupakan salah satu industri yang diminati oleh pelaku usaha karena pengerjaanya yang sederhana dan produk yang dihasilkan memiliki nilai seni yang indah dan juga nilai guna yang tinggi bagi konsumen.

Industri kerajinan bambu saat ini banyak ditemui di Provinsi Sulawesi Utara sumber yang mudah ditemui, baik sumber daya alamnya maupun sumber daya manusia dengan teknologi yang sederhana ternyata mampu mendatangkan keuntungan.

Meras adalah salah satu Kelurahan di Kecamatan Bunaken Kota Manado Provinsi Sulawesi utara yang memiliki sumber daya alam bambu batik yang dapat diolah menjadi berbagai produk kerajinan bambu. Satu-satunya industri kerajinan bambu batik di Kelurahan Meras yaitu kerajinan bambu batik UD. Betris.

Menjalankan suatu usaha tentu mempunyai tujuan agar tetap mampu berkembang dan bersaing dengan kompetitornya sehingga penjualan dan pendapatan diharapkan selalu meningkat, hal ini tidak terlepas dari pentimgnya peran strategi bisnis yang diterapkan oleh lini usaha termasuk industri kerajinan bambu batik UD. Betris di Kelurahan Meras Kecamatan Bunaken Kota Manado.

Oleh karena itu, perlu dilakukan kajian strategi pengembangan usaha agar usaha kerajinan bambu dapat meningkatkan daya saing agar dapat bertahan dalam berbagai situasi dan kondisi. Dalam pengembangan usaha diperlukan strategi yang tepat untuk mengembangkan usaha kerajinan bambu ini.

\section{Rumusan Masalah}

Berdasarkan latar belakang yang telah di kemukakan maka permasalahan dalam penelitian ini adalah:

1. Apa yang menjadi faktor internal dan faktor eksternal dari industri kerajinan bambu batik UD. Betris yang ada di Meras ?

2. Strategi apa yang dapat diterapkan dalam pengembangan industri kerajinan bambu batik UD. Betris di Meras?

\section{Tujuan Penelitian}

Adapun tujuan penelitian yang ingin dicapai dalam penelitian ini yaitu:

1. Menganalisis faktor internal dan faktor eksternal industri kerajinan bambu batik UD. Betris di Meras.

2. Untuk merumuskan strategi pengembangan industri kerajinan bambu batik UD. Betris di Meras.

\section{Manfaat Penelitian}

Penelitian ini diharapkan dapat memberikan manfaat antara lain:

1. Bagi industri rumah tangga kerjinan bambu batik UD. Betris memberikan informasi dan bahan pertimbangan strategi-strategi yang dapat dilakukan agar dapat mengembangkan usahanya menjadi lebih baik. 
2. Bagi penulis, penelitian ini diharapkan dapat memberikan tambahan pengetahuan.

3. Bagi pemerintah khususnya Daerah Meras agar dapat mengembangkan usaha kerajinan bambu batik UD. Betris, dan pertimbangan yang dapat dijadikan sebagai kebijakan-kebijakan yang dapat membantu agar usaha tersebut terus berkembang.

\section{METODE PENELITIAN}

\section{Waktu dan Tempat Penelitian}

Penelitian ini dilaksanakan selama 3 bulan yaitu dari bulan April sampai bulan Juni tahun 2018 yaitu persiapan sampai penysunan selesai. Tempat penelitian adalah usaha rumah tangga kerajinan bambu yang berlokasi di Kelurahan Meras Kecamatan Bunaken Kota Manado.

\section{Metode Pengambilan Data}

Data yang digunakan pada usaha kerajinan bambu batik UD. Betris di Kelurahan Meras adalah data primer dan data sekunder. Data primer berupa data faktor-faktor internal (kekuatan - kelemahan) dan eksternal (peluangancaman) dari usaha Kerajinan Bambu Batik UD. Betris. Data sekunder di peroleh dari studi literatur yang berkaitan dengan data yang dibutuhkan dalam studi kasus.

Data yang diperoleh akan disajikan dalam bentuk tabel dan di analisis secara deskriptif. Pengumpulan seluruh data yang diperlukan untuk studi kasus pada usaha kerajinan bambu batik UD. Betris menggunakan beberapa cara yaitu :

1. Wawancara. Teknik ini digunakan untuk mengumpulkan data primer dengan wawancara langsung kepada responden yaitu pemilik usaha kerajinan bambu batik UD. Betris berdasarkan pertanyaan (kuesioner) yang telah dipersiapkan.

2. Pencatatan. Teknik ini digunakan untuk mengumpulkan data sekunder dari instansi atau lembaga yang mendukung penelitian.

3. Studi literatur dan kepustakaan. Studi literatur dan kepustakaan dilakukan melalui studi pustaka berbagai jurnal ilmiah dan skripsi, artikel-artikel yang relevan, serta sumber lain yang mendukung data sekunder.

\section{Pengukuran Variabel}

\section{Faktor Internal}

Faktor dalam adalah faktor yang secara teknis dan logis harus dapat dikendalikan, faktor ini juga bisa merupakan kelemahan. Faktor ini diantaranya:

a. Produksi meliputi:

1. Mesin - mesin

2. Ketersediaan bahan baku

b. Pemasaran meliputi:

1. Produk

2. Harga produk

3. Lokasi penjualan

4. Promosi

c. Keuangan meliputi:

1. Pembukuan

\section{Faktor ekstenal}

Faktor eksternal adalah semua faktor dari luar yang relatif sulit dikendalikan. Faktor ini dapat merupakan peluang, tetapi sekaligus juga ancaman.
a. Pesaing
b. Minat generasi penerus
c. Dukungan pemerintah

\section{Metode Analisis Data}

\section{Analisis Deskriptif}

Penulis menggunakan metode penelitian analisis deskriptif dengan yaitu dengan cara menggambarkan dan membahas keadaan serta kegiatan dalam industri Kerajinan Bambu Batik UD. Betris di Kelurahan Meras berdasarkan data dan informasi yang didapat dan dikumpulkan.

\section{Analisis SWOT}

Menurut Rangkuty (2017), cara perhitungan bobot dan rating dalam analisis SWOT dengan menggunakan kuesioner yaitu:

a. Kuesioner penilaian bobot menggunaka skala likert 
Nilai $1=$ Tidak Penting

Nilai $2=$ Kurang Penting

Nilai $3=$ Cukup Penting

Nilai $4=$ Penting

Nilai $5=$ Sangat Penting

b. Kuesioner penilaian rating menggunakan skala likert

Untuk Faktor Kekuatan dan Peluang

Nilai $1=$ Kecil

Nilai 2 = Cukup Besar

Nilai $3=$ Besar

Nilai 4 = Sangat Besar

Untuk Faktor Kelemahan dan Ancaman

Nilai $1=$ Sangat Besar

Nilai $2=$ Besar

Nilai 3 = Cukup Besar

Nilai $4=$ Kecil

Dalam penelitian ini penulis menggunakan kuesioner untuk menentukan atau memperoleh nilai bobot dan rating.

\section{HASIL DAN PEMBAHASAN}

\section{Deskripsi Umum Tempat Penelitian}

\section{Sejarah Berdirinya Usaha Industri Kerajinan Bambu Batik UD. Betris}

Usaha Kerajinan Bambu Batik UD Betris berdiri sejak tahun 2015, Pendiri usaha ini bernama Ibu Bertha Mansauda. Usaha ini mampu bertahan melawan perkembangan jaman yang semakin modern.

Usaha kerajinan bambu batik UD Betris di kelurahan Meras termasuk dalam industri rumah tangga (home industry) dikatakan Industri Rumah Tangga karena kegiatan industri dilakukan di rumah tangga, tenaga kerja yang dipekerjakan tidak lebih dari 3 orang dan peralatan yang digunakan mulai dari manual hingga alat semi otomatis. (Abrianto 2012:37).

Usaha kerajinan bambu batik UD. Betris selalu aktif mengikuti berbagai pameran diantaranya:

1. Pameran Hut Provinsi Sulawesi Utara yang disponsori oleh Disperindag Kota Manado pada tahun 2016 yang diselenggarakan di Desa Kayuwatu.
2. Pameran Nusantara Expo mengikuti lomba kerajinan yang diselenggarakan di Jakarta membawa nama Pemerintah Kota Manado dan mendapat juara 1 pada tahun 2016.

3. Pameran Kriya dan Boga Sulawesi utara yang disponsori oleh Bank Indonesia pada tahun 2017.

4. Mengikuti pameran Manado Viesta yang disponsori oleh Disperindag dan Dinas koperasi pada tahun 2017.

5. Dinas sosial membeli produk kerajinan bambu batik UD. Betris untuk mengikuti pameran yang diselenggarakan dikota Palu.

Dari hasil mengikuti pameranpameran tersebut, usaha Kerajinan Bambu Batik UD. Betris mendapatkan pasar lokal maupun mancanegara. Untuk pasar lokal terdapat di beberapa daerah di Sulawesi Utara khususnya Walikota Kota Manado yang membeli Mniatur Kantor Walikota. Sedangkan untuk pasar ekspor yaitu Lukisan Capung dari bambu yang diekspor ke negara Belanda dan Bunga Rangkai yang diekspor ke negara China.

\section{Produk yang Dihasilkan}

Produk kerjinan bambu yang dihasilkan oleh para pengrajin bervariasi, namun beberapa jenis kerajinan yang rutin dan secara teratur dibuat oleh pengarjin terdiri dari 2 macam yaitu souvenir dan miniatur.

1. Souvenir: Gantungan kunci, kalung, anting, jepitan rambut, mangkok, dan tetengkoreng.

2. Miniatur : Rumah panggung, kapal, kursi set, bunga rangkai, dan pesawat.

\section{Struktur Organisasi dan Tenaga Kerja}

Industri kerajinan bambu batik UD. Betris Sentra Kerajinan Bambu merupakan industri rumah tangga yang memiliki tenaga kerja 2 orang seperti yang tertuang dalam Gambar 3. Ketua saat ini diduduki oleh Ibu Bertha Mansauda sebagai pemilik sekaligus pembuat kerajinan bambu batik UD. Betris dan 2 orang tenaga kerja sebagai pemotong dan pengamplas bambu. 


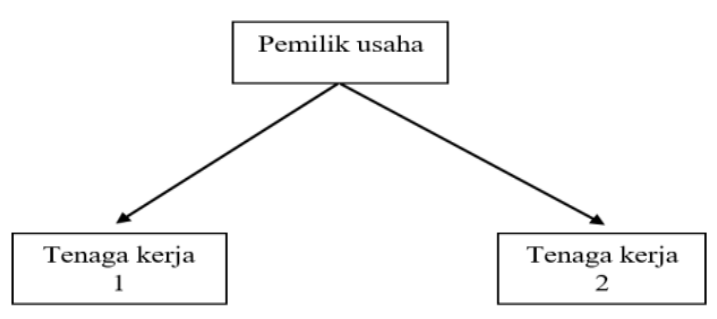

Gambar 1. Struktur Organisasi

\section{Identifikasi Faktor Internal dan Faktor Eksternal}

\section{Faktor Internal}

1. Bahan Baku

Bahan baku utama produk kerajinan bambu batik UD. Betris adalah Bambusa maculata atau bambu tutul salah satu spesies bambu di Indonesia, Jenis bambu ini memiliki tampilan sangat unik karena pola coklatnya, Tanaman ini memiliki panjang rata-rata hingga 20 meter dengan diameter hingga $12 \mathrm{~cm}$. Bambu ini bisa bertahan hidup pada wilayah dingin asalkan dengan suhu tidak kurang dari $2^{\circ} \mathrm{C}$. Sehingga tumbuhan ini bisa dibudidayakan di dataran rendah maupun pegunungan dan di wilayah tropis maupun sub tropis. Bahan baku bambu tutul diperoleh di daerah Meras dari kebun milik pengrajin yang letaknya tidak jauh dari tempat usaha, ketika pesanan banyak bahan baku diperoleh juga dari petani bambu dengan harga yang sangat murah yaitu Rp.10.000/ ujung.

2. Standart Dan Kualitas Bahan Baku

Standart dan kualitas bahan baku bambu tutul ini berkualitas ketika umur bambu sudah tua dan pengrajin selalu memakai bambu yang sudah tua, keunikan dari bambu ini yaitu totol-totol cokelat pada bambu yang menyerupai batik sehingga bambu ini sangat cocok dibuat kerajinan karena berkualitas dan memiliki nilai seni yang tinggi. Semakin tua umur bambu tutul semakin banyak totol-totol yang menyerupai batik yang terdapat pada bambu.

3. Keterampilan Dan Jiwa Bisnis Pengrajin

Keterampilan dan jiwa bisnis yang dimiliki pengrajin bambu ini sudah sangat terlatih, sehingga pengrajin mampu mengembangkan usaha kerajinannya dengan tingkat kesabaran dan semangat juang yang tinggi menghasilkan produk yang sangat unik dan bernilai seni yang tinggi.

\section{Keunikan Produk}

Produk kerajinan bambu batik UD. Betris dapat dikatakan sebagai kerajinan yang memiliki keunikan dan nilai seni yang tinggi karena bahan baku utama yaitu bambu tutul yang memiliki totol-totol cokelat menyerupai batik dan bentuknya yang beragan.

5. Penentuan Harga Jual Produk

Usaha ini termasuk usaha kreatif, maka komponen biaya bahan baku tidak menjadi patokan mutlak dalam penentuan harga jual, namun lebih kepada lama waktu yang dibutuhkan dalam membuat produk, tingkat kesulitan dan desain dari produk. Menurut pemilik usaha dan konsumen yang diwawancarai harga produk masih terjangkau, harga produk yang ditentukan oleh pemilik usaha yaitu:

- Rp.5.000-Rp.35.000 yaitu souvenir (gantungan kunci, kalung, anting, tetengkoreng, mangkok), proses pembuatan tidak sulit dan memerlukan waktu sehari.

- Rp.55.000-Rp.225.000 yaitu miniatur (kursi set, pesawat, bunga rangkai dan vas bunga), proses pembuatan memerlukan waktu 2-3 hari.

- Rp.300.000-Rp.750.000 yaitu miniatur (rumah panggung, rumah adat Minahasa, kantor walikota, zero point), proses pembuatan memerlukan waktu 5-7 hari.

6. Ketahanan Dan Kualitas Produk

Produk yang dihasilkan oleh kerajinan bambu batik UD. Betris dapat bertahan sampai bertahun-tahun karena keterampilan tangan pengrajin dan ketelitiannya sehingga membuat produk yang tahan lama. pengrajin juga mengutamakan kualitas bahan baku yang digunakan untuk membuat kerajinan agar produk yang dihasilkan tahan lama.

\section{Pencatatan Keuangan}

Pencatatan keuangan dalam usaha ini belum lengkap hanya mengandalkan nota bukti pembayaran, tidak ada catatan secara lengkap tentang pengeluaran, pendapatan, dan keuntungannya. 


\section{Proses Produksi}

Proses produksi usaha ini belum menggunakan teknologi canggih, tetapi masih menggunakan alat tradisional seperti pisau, parang, ban scrub, mesin bor, gurinda, dan gergaji. Proses produksinya yaitu pemotongan bambu sesuai ukuran yang dibutuhkan dengan menggunakan tangan dan keahlian sehingga bambu dipotong dengan berbagai bentuk dengan tangan pengrajin, kemudian di amplas sehingga mendapatkan permukaan bambu yang halus, setelah itu dirangkai dengan menggunakan lem untuk membentuk produk dengan berbagai model kerajinan dan untuk mendapatkan hasil yang bagus digunakan pewarna (cat dan politur) sesuai dengan kebutuhan.

9. Kenyamanan Tempat Usaha

Usaha ini membutuhkan bangunan khusus tempat usaha agar penataan produk dan bahan bakunya dapat tertata rapi, selain itu kenyamanan tempat usaha yaitu belum adanya tempat parkir bagi para konsumen yang mengunjungi tempat usaha.

10. Metode Promosi

Metode promosi yang digunakan yaitu media sosial seperti facebook, namun akun facebook masih terkait dengan kegiatan pribadi pengrajin, seharusnya memiliki akun khusus untuk produk yang dihasilkan agar konsumen mudah mendapatkan informasi tentang produk kerajinan bambu batik UD. Betris.

\section{Faktor Eksternal}

\section{Peluang Pasar}

Usaha kerajinan bambu batik UD. Betris di Kelurahan Meras memiliki potensi dan peluang pasar yang sangat luas karena usaha ini menjalin kerja sama dengan dinas-dinas terkait yaitu Dinas Sosial, Dinas Perindustrian dan Perdagangan, dan Dinas Koperasi melalui pameran-pameran sehingga usaha ini dikenal oleh masyarakat lokal bahkan sampai mancanegara sejauh ini kerajinan bambu batik telah mengekspor produknya ke luar negeri yaitu China dan Belanda. Karena keberhasilan usaha ini pemilik sekaligus pengrajin memiliki kesempatan menjadi narasumber di berbagai pelatihan usaha-usaha kecil dan menengah khususnya memanfaatkan limbah industri sehingga dengan pelatihan tersebut produk banyak dikenal dan laku terjual.

2. Dukungan Pemerintah

Usaha ini telah mendapatkan surat izin usaha perdagangan dengan dukungan pemerintah dan juga telah mendapat bantuan berupa alat-alat produksi yang digunakan dalam proses pembuatan produk.

\section{Adanya pesaing}

Perkembangan teknologi yang ada saat ini telah memberikan persaingan terhadap kerajinan ini dengan bahan baku berbeda. Salah satunya bahan baku batok kelapa yang telah menggunakan mesin pemotong yang canggih sehingga menciptakan produk dengan berbagai bentuk dan model. Selain bahan baku batok kelapa ada juga yang berbahan baku plastik, dimana bahan baku plastik ini memiliki daya tahan yang sangat lama.

4. Kurangnya Minat Generasi Penerus Usaha

Permasalahan yang dihadapi oleh kerajinan bambu batik UD. Betris adalah kurangnya minat generasi muda untuk bekerja sebagai penerus usaha ini. generasi muda tentunya akan menjadi harapan selanjutnya bagi keberlangsungan dan perkembangan usaha kerajinan bambu batik UD. Betris. jika tidak ada generasi penerus maka usaha ini tidak akan bertahan lebih lama.

Berdasarkan uraian yang telah dikemukakan maka di identifikasi faktor internal dan faktor eksternal yang di sajikan dalam Tabel 1.

\begin{tabular}{|c|c|}
\hline Faktor Intemal & Faktor Ekstemal \\
\hline Kekuatan & Peluang \\
\hline 1. Ketersediaan bahan baku & 1. Peluang pasar yang tinggi \\
\hline 2. Standart dan kualitas bahan baku & 2. Dukungan pemerintah \\
\hline 3. Harga bahan baku yang murah & 3. Kesempatan mengikuti pelatihan \\
\hline 4. Keunikan produk yang dihasilkan & 4. Peningkatan permintaan konsumen \\
\hline \multicolumn{2}{|l|}{ 5. Jiwa bisinis pengrajin } \\
\hline \multicolumn{2}{|l|}{ 6. keterampilan pengrajin } \\
\hline \multicolumn{2}{|l|}{ 7. Harga jual yang terjangkau } \\
\hline \multicolumn{2}{|l|}{ 8. Ketahanan dan kualitas produk } \\
\hline Kelemahan & Ancaman \\
\hline 1. Belum memiliki pencatatan keuangan yang lengkap & 1. Barang subtitusi berbahan baku plastik \\
\hline 2. Alat produksi yang masih tradisional & 2. Kurangnya minat penerus usaha untuk \\
\hline 3. Penataan produk yang belum tertata rapi & menjalankan dan mempertahankan \\
\hline 4. Metode promosi yang dilakukan belum efisien & usaha \\
\hline 5. Belum memiliki tempat khusus untuk usaha & 3. Adanya pesaing dengan menggunakan \\
\hline 6. Belum ada lahan parkir untuk pengunjung (konsumen) & alat produksi yang lebih canggih \\
\hline
\end{tabular}




\section{Strategi Pengembangan Usaha Industri Kerajinan Bambu Batik UD. Betris}

\section{Hasil Evaluasi Lingkungan Internal (IFAS) dan Hasil Evaluasi Lingkungan Eksternal (EFAS)}

Setelah dilakukan identifikasi terhadap faktor internal dan eksternal yang berpengaruh terhadap perkembangan usaha kerajinan bambu batik UD. Betris maka selanjutnya dilakukan evaluasi terhadap faktor-faktor tersebut baik dari kekuatan dan kelemahan yang ada dengan menggunakan Analisis Internal Faktor Strategi (IFAS), dan faktor-faktor peluang dan ancaman yang ada dengan menggunakan Analisis Eksternal Faktor Strategi (EFAS) Berdasarkan evaluasi yang dilakukan di peroleh hasil bobot, rating, dan nilai skor yang dapat dilihat pada Tabel 2 dan 3.

\begin{tabular}{lccc} 
Tabel 2. Strategi Internal Usaha Kearajinan Bambu Batik UD. Betris \\
\hline \multicolumn{1}{c}{ Faktor-faktor strategi intemal } & Bobot & Rating & Skor \\
\hline No & & & \\
\hline Kekuatan & 0,137 & 4 & 0,548 \\
1. Bahan baku yang muda didapat & 0,124 & 4 & 0,496 \\
2. Kualitas bahan baku baik & 0,120 & 4 & 0,48 \\
3. Harga bahan baku yang relatif murah & 0,120 & 4 & 0,48 \\
4. Keunikan produk yang dihasilkan & 0,124 & 4 & 0,496 \\
5. Jiwa bisnis pengrajin & 0,124 & 4 & 0,496 \\
6. keterampilan pengrajin & 0,134 & 4 & 0,536 \\
7. Harga produk yang terjangkau & 0,117 & 4 & 0,468 \\
8. Ketahanan dan kualitas produk & 1 & & 4 \\
\hline Total & & & \\
Kelemahan & 0,119 & 2,5 & 0,2975 \\
1. Belum memiliki pencatatan keuangan yang lengkap & 0,085 & 1,12 & 0,0952 \\
2. Alat produksi yang masih tradisional & 0,188 & 1 & 0,188 \\
3. Penataan produk yang belum tertata rapi & 0,205 & 1,25 & 0,2562 \\
4. Metode promosi yang dilakukan belum efisien & 0,198 & 1,12 & 0,2217 \\
5. Belum memiliki tempat khusus untuk usaha & 0,205 & 1,12 & 0,2296 \\
6. Belum ada tempat parkir untuk pengunjung & 1 & & 1,2882 \\
\hline Total & &
\end{tabular}

Total bobot $\mathrm{x}$ rating pada Tabel 2 menunjukkan faktor kekuatan bernilai 4 dan faktor kelemahan bernilai 1,2882 yang digunakan sebagai acuan titik kondisi internal pada usaha kerajinan bambu batik UD.Betris hasil ini digunakan untuk melihat posisi perusahaan saat ini.

\begin{tabular}{l} 
Tabel 3. Strategi Eksternal Usaha Kearajinan Bambu Batik UD. Betris \\
\begin{tabular}{llccc}
\hline \multicolumn{1}{c}{ Faktor-faktor strategi ekstemal } & Bobot & Rating & Skor \\
\hline No. & & & \\
\hline & Peluang & 0,263 & 4 & 1,052 \\
1. Peluang pasar yang tinggi & 0,270 & 3,87 & 1,044 \\
2. Adanya dukungan pemerintah & 0,229 & 3,12 & 0,714 \\
3. Kesempatan mengikuti pelatihan & 1 & & 3,778 \\
4. Peningkatan permintaan konsumen dengan adanya pameran & 0,238 & 3,25 & 0,968 \\
\hline & Total & 0,163 & 2,12 & 0,345 \\
\hline & Ancaman & 0,656 & 1 & 0,656 \\
1. Barang subtitusi berbahan baku plastik & 0,181 & 2,25 & 0,407 \\
2. Kurangnya minat penerus usaha & 1 & & 1,408 \\
3. Adanya pesaing dengan menggunakan alat produksi modem
\end{tabular} \\
\hline
\end{tabular}

Berdasarkan hasil matriks IFAS dapat dilihat bahwa faktor strategis internal kekuatan memiliki nilai skor sebesar 4 sedangkan faktor strategis internal kelemahan memiliki nilai skor sebesar 1,2882. Hal ini menunjukan bahwa faktor kekuatan lebih tinggi dibandingkan dengan faktor kelemahan. Selanjutnya, hasil matriks EFAS pada faktor strategis eksternal peluang memiliki nilai skor sebesar 3,778 sedangkan faktor strategis eksternal ancaman memiliki nilai skor sebesar 1,408. Hal ini berarti industri kerajinan bambu batik UD. BETRIS di Kelurahan Meras memiliki peluang yang lebih besar untuk mengantisipasi ancaman dalam menentukan strategi pengembangannya

\section{Diagram Analisis SWOT}

Berdasarkan hasil perhitungan skor faktor strategis internal dan eksternal maka dapat diketahui bahwa nilai $\mathrm{x}$ sebagai sumbu horizontal yaitu faktor kekuatan 4 dikurangi faktor kelemahan 1,2882 dengan selisih 2,7118 dan nilai sumbu y sebagai sumbu vertikal yaitu faktor peluang 3,778 dikurangi faktor ancaman 1,408 dengan selisih 2,370. Dengan demikian nilai sumbu $\mathrm{x}$ dalam diagram SWOT adalah 2,7118 dan nilai sumbu y dalam diagram analisis SWOT adalah 2,370.

Hasil identifikasi faktor-faktor tersebut maka dapat digambarkan dalam diagram SWOT sebagai berikut:

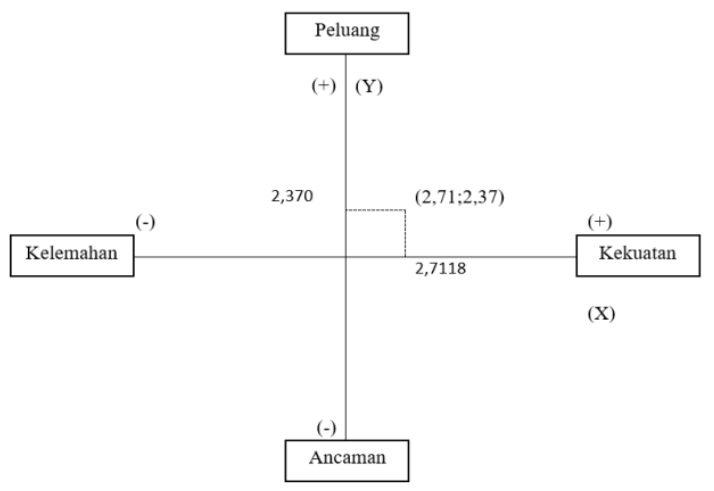

Gambar 2. Diagram Analisis SWOT

Pada Gambar 2 diagram analisis SWOT menunjukkan bahwa usaha kerajinan bambu batik UD. Betris memiliki kekuatan dan peluang sehingga dapat memanfaatkan peluang yang ada. Strategi yang dapat diterapkan dalam 
kondisi ini adalah mendukung kebijakan pertumbuhan yang agresif (Growth oriented strategy) (Rangkuti, 2017:20).

Hal ini berarti usaha kerajinan bambu batik UD. Betris di Kelurahan Meras memiliki kekuatan yang lebih besar untuk menghadapi kelemahannya dan peluang yang lebih besar untuk mengantisipasi ancaman dalam menentukan strategi pengembangannya.

\section{Matriks SWOT}

\section{Tabel 4. Matriks SWOT}

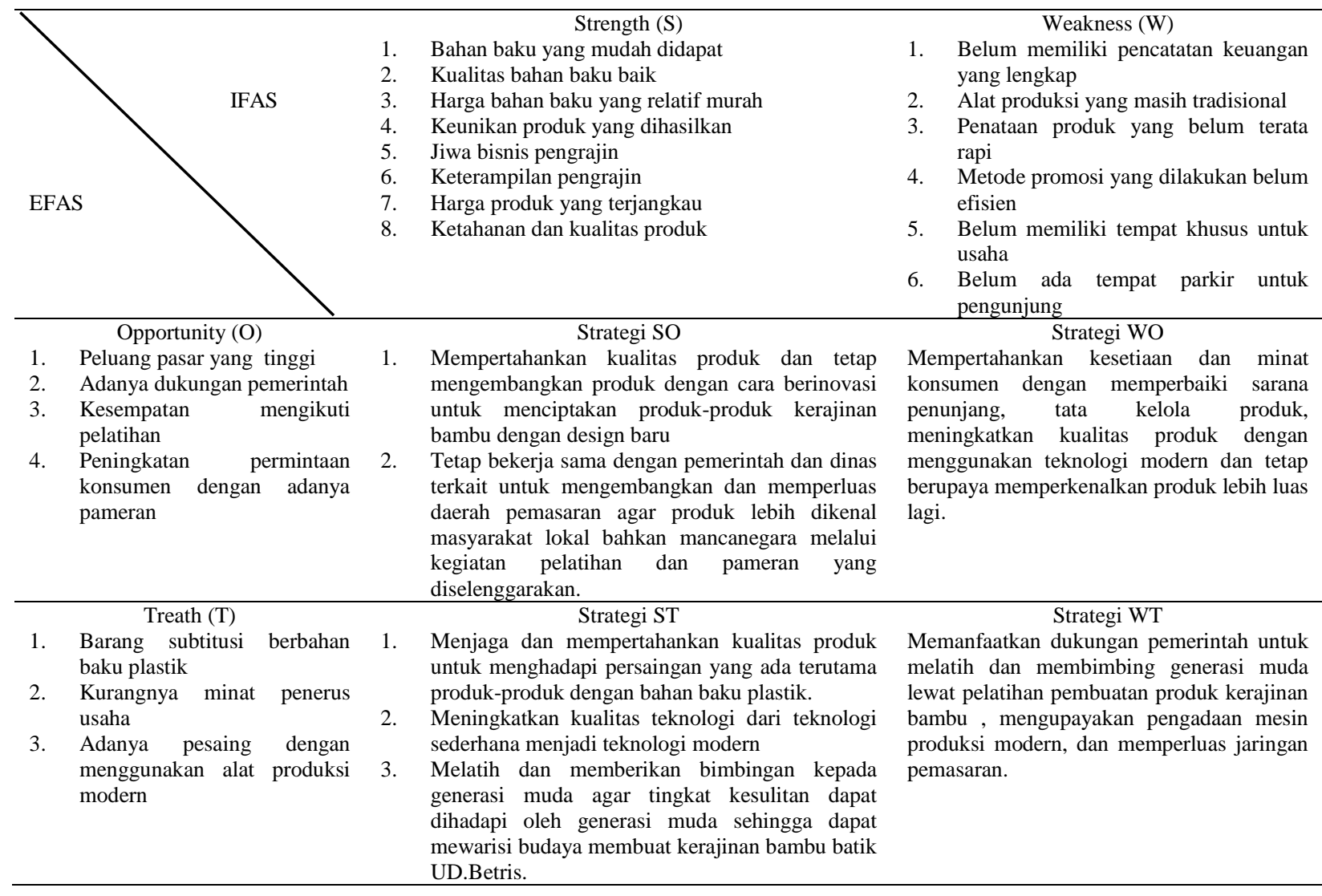

Berdasarkan Tabel 4 diperoleh beberapa alternatif strategi yang bisa diaplikasikan dalam pengembangan usaha kerajinan bambu batik UD. Betris di kelurahan Meras dalam upaya untuk memaksimalkan kekuatan dan memanfaatkan peluang serta meminimalkan kelemahan dan mengatasi ancaman yang ada adalah sebagai berikut:

I. Strategi SO

a. Mempertahankan kualitas produk dan tetap mengembangkan produk dengan cara berinovasi untuk menciptakan produk-produk kerajinan bambu dengan design baru.

b. Tetap bekerja sama dengan pemerintah dan dinas terkait untuk mengembangkan dan memperluas daerah pemasaran agar produk lebih dikenal masyarakat lokal bahkan mancanegara melalui kegiatan pelatihan dan pameran yang diselenggarakan.

II. Strategi WO

Mempertahankan kesetiaan dan minat konsumen dengan memperbaiki sarana penunjang, tata kelola produk, meningkatkan kualitas produk dengan menggunakan teknologi modern dan tetap berupaya memperkenalkan produk lebih luas lagi.

III. Strategi ST

1. Menjaga dan mempertahankan kualitas produk untuk menghadapi persaingan yang ada terutama produk-produk dengan bahan baku plastik. 
2. Meningkatkan kualitas teknologi dari teknologi sederhana menjadi teknologi modern.

3. Melatih dan memberikan bimbingan kepada generasi muda agar tingkat kesulitan dapat dihadapi oleh generasi muda sehingga dapat mewarisi budaya membuat kerajinan bambu batik UD. Betris.

IV. Strategi WT

Memanfaatkan dukungan pemerintah untuk melatih dan membimbing generasi muda melalui pelatihan pembuatan produk kerajinan bambu, mengupayakan pengadaan mesin produksi modern, dan memperluas jaringan pemasaran. Posisi usaha kerajinan bambu batik UD. Betris di kelurahan Meras dalam diagram SWOT menunjukan bahwa usaha ini berada pada kuadran I (satu). Artinya strategi yang tepat untuk digunakan dalam usaha kerajinan bambu Batik UD. Betris di Kelurahan Meras adalah strategi SO yaitu dengan upaya memaksimalkan kekuatan dan memanfaatkan peluang, dengan tetap meninjau atau meperhatikan tiga strategi lainnya yaitu strategi WO, strategi ST, dan strategi WT.

\section{KESIMPULAN DAN SARAN}

\section{Kesimpulan}

a. Faktor internal meliputi: Bahan baku, Kualitas bahan baku, Harga bahan baku, Keunikan produk, Jiwa bisnis dan keterampilan pengrajin, Harga produk, Ketahanan dan kualitas produk, Belum memiliki pencatatan keuangan, Alat produksi tradisional, Penataan produk yang belum tertata rapi, Promosi belum efisien, Belum memiliki tempat khusus usaha, dan Belum ada tempat parkir. Sedangkan faktor eksternal meliputi: Peluang pasar yang tinggi, Dukungan pemerintah, Kesempatan mengikuti pelatihan, Kesempatan mengikuti pameran, Barang subtitusi berbahan baku plastik, Minat penerus usaha, dan Adanya pesaing dengan menggunakan alat produksi modern. b. Strategi yang tepat untuk pengembangan Usaha Industri Kerajinan Bambu Batik UD. Betris di Kelurahan Meras Kecamatan Bunaken Kota Manado adalah dengan menerapkan strategi agresif, yaitu strategi SO dengan Mempertahankan kualitas produk dan tetap mengembangkan produk dengan cara berinovasi untuk menciptakan produk-produk kerajinan bambu dengan design baru dan Tetap bekerja sama dengan pemerintah dan dinas terkait untuk mengembangkan dan memperluas daerah pemasaran agar produk lebih dikenal masyarakat lokal bahkan mancanegara melalui kegiatan pelatihan dan pameran yang diselenggarakan.

Selain menggunakan strategi SO sebagai pilihan strategi utama, juga harus tetap memperhatikan atau meninjau ketiga alternatif strategi lainnya yaitu strategi WO, strategi ST, dan strategi WT.

\section{Saran}

1. Bagi pemilik Usaha Kerajinan Bambu Batik UD. Betris yaitu tetap Mempertahankan kualitas produk dan tetap mengembangkan produk dengan cara berinovasi untuk menciptakan produk-produk kerajinan bambu dengan design baru dan Tetap bekerja sama dengan pemerintah dan dinas terkait untuk mengembangkan dan memperluas daerah pemasaran agar produk lebih dikenal masyarakat lokal bahkan mancanegara melalui kegiatan pelatihan dan pameran yang diselenggarakan.

2. Pemerintah Kota Manado untuk dapat memfasilitasi dengan pengadaan alat produksi modern agar usaha kerajinan bambu batik UD. Betris dapat lebih berkembang dan tetap bertahan di zaman yang semakin modern ini.

\section{DAFTAR PUSTAKA}

Abrianto. 2012. Pertanggung Jawaban Terhadap Produk Industri Rumah Tangga (Home Industry) Tanpa Izin Dinas Kesehatan. Skripsi. Makassar: Fakultas Hukum. UNHAS. 
Rangkuty, F. 2017. Analisis SWOT Teknik

Membedah Kasus Bisnis. PT.Gramedia

Pustaka Utama. Jakarta. 